\title{
Dye-Sensitized Solar Cells with Zinc Oxide Nanostructured Films Made with Amine Oligomers as Organic Templates and Gel Electrolytes
}

\author{
Andigoni Apostolopoulou, Dimitris Karageorgopoulos, Andreas Rapsomanikis, and Elias Stathatos
}

\begin{abstract}
The demand for energy led to clean, renewable and cheap energy sources, while solar energy is the most abundant. Dye sensitized solar cells (DSSCs) are proposed as low cost alternatives to the conventional photovoltaics. These cells have been widely examined due to their low cost and high conversion efficiency. Several mesoporous metal oxides have been examined, where $\mathrm{ZnO}$ nanostructures have been taken much attention last years.

At the present work, we examine the use of nanostructured $\mathrm{ZnO}$ films as photoanodes in DSSCs. The simplicity of the $\mathrm{ZnO}$ films synthesis is demonstrated while solar cells are constructed and tested. In particular, we demonstrate a simple method combining $\mathrm{Zn}\left(\mathrm{NO}_{3}\right)_{2}$ as zinc precursor with different organic templates. Besides, the structural properties of the $\mathrm{ZnO}$ films are examined with porosimetry, microscopy methods and $X$-Ray diffractograms. Their electrical behavior is examined in terms of current-voltage characteristic curves under simulated solar light while electrochemical impedance spectroscopy is also used for measuring charge transfer across the $\mathrm{ZnO}$-electrolyte interface and free electron lifetimes. We finally obtained an overall efficiency of $0.6 \%$ for DSSCs based on $\mathrm{ZnO}$ films and a commercial dye as sensitizer. It seems that $\mathrm{ZnO}$ films constitute promising nanostructures for DSSCs that can be further improved.
\end{abstract}

Index Terms-Dye-sensitized solar cells, photoanodes, thin films, zinc oxide.

\section{INTRODUCTION}

DSSCs have attracted much attention due to their low cost manufacturing, fabrication on flexible substrate and simple construction [1], [2]. Despite these advantages, the maximum certified efficiency for DSSCs is much lower compared to silicon based solar cells. Much research has been focused to enhance the performance of DSSCs with different anode materials such as $\mathrm{TiO}_{2}, \mathrm{ZnO}, \mathrm{SnO}_{2}, \mathrm{Nb}_{2} \mathrm{O}_{5}$ etc. while $\mathrm{TiO}_{2}$ is dominated most of times [3]-[8]. Recently, $\mathrm{ZnO}$, with similar band gap to that of $\mathrm{TiO}_{2}$, appears to be an alternative material for the fabrication of high efficiency DSSCs. It possesses

Manuscript received April 19, 2015; revised August 28, 2015. This research has been co-financed by the European Union (European Social Fund - ESF) and Greek national funds through the Operational Program "Education and Lifelong Learning" of the National Strategic Reference Framework (NSRF) - Research Funding Program: Thales MIS: 377756.

Andigoni Apostolopoulou and Dimitrios Karageorgopoulos are with the Physics Department, University of Patras, 26500, Greece (e-mail: and.apostolopoulou@gmail.com, dkarageorgop@upatras.gr).

Andreas Rapsomanikis is with the Geology Department, University of Patras, 26500, Greece (e-mail: rapsosan@gmail.com).

Elias Stathatos is with the Electrical Engineering Department, Technological-Educational Institute of Western Greece, 26334 Patras, Greece (tel.: 0030-2610-369242; e-mail: estathatos@ teiwest.gr). high environmental stability and high electron mobility, providing a direct conduction pathway for rapid collection of electrons at the substrate of the photoanode [9]-[11]. $\mathrm{ZnO}$ is also a wide band gap semiconductor with energy band structure and physical properties similar with $\mathrm{TiO}_{2}$. However, it has higher electron mobility $\left(155 \mathrm{~cm}^{2} \mathrm{v}^{-1} \mathrm{~s}^{-1}\right.$ versus to $10^{-5}$ $\mathrm{cm}^{2} \mathrm{v}^{-1} \mathrm{~s}^{-1}$ of $\mathrm{TiO}_{2}$ ) favorable for electron transport, it is easily crystallized and anisotropically grow in a variety of morphologies such as nanowires, nanotubes, nanobelts, and nanoflowers [12]-[15]. Due to their aforementioned unique properties they have been proposed as alternative photoelectrodes in DSSCs in order to achieve better performance. In this work we report the synthesis and characterization of different $\mathrm{ZnO}$ photoanodes for dye sensitized solar cells. The simplicity of depositing $\mathrm{ZnO}$ films applied as photoanodes has been presented, while their electrical properties were studied, as solar cells with a ruthenium complex dye (N719) as sensitizer. In particular, the structural properties of the films with different organic materials as templates were examined in terms of their porosity using BET method and FE-SEM microscopy. More porous films were prepared when organic template with higher molecular weight was used. According to FE-SEM images, particles with average diameter of $30-60 \mathrm{~nm}$ were prepared depending on the template. Furthermore, a better performance of DSSCs and improved electrical characteristics were obtained in the case of more porous films. This study attempts to take advantage of the proposed synthetic route of $\mathrm{ZnO}$ to prepare photoanodes for DSSCs but also for other applications that require nanocrystalline films of transition metal oxides.

\section{EXPERIMENTAL}

\section{A. Materials}

Zinc nitrate hexahydrate $\left(\mathrm{Zn}\left(\mathrm{NO}_{3}\right)_{2} \cdot 6 \mathrm{H}_{2} \mathrm{O}\right)$, poly (propylene glycol) bis (2-aminopropyl) ether (APPG) with different chain lengths $M_{\mathrm{r}} \approx 230,400,2000$ were used to make different precursor sols. Lithium iodide (LiI), iodine $\left(\mathrm{I}_{2}\right)$, 1-methyl-3-propyl imidazolium iodide (MPII), guanidine thiocyanate $(\mathrm{Gu}-\mathrm{SCN})$, acetic acid $(\mathrm{AcOH}), 4$-tert-butyl pyridine (TBP), 3-isocyanatopropyl triethoxy silane (ICS) were purchased from Sigma-Aldrich and used as received.Chloroplatinic acid hexahydrate $\left(\mathrm{H}_{2} \mathrm{PtCl}_{6}\right)$ and all solvents were also purchased from Aldrich and used as received. Cis-diisothiocyanato-bis (2,2'-bipyridyl-4,4'dicarboxylato) ruthenium(II) bis(tetrabutylammonium), N719 was purchased from Solaronix S.A, Switzerland. $\mathrm{SnO}_{2}$ : $\mathrm{F}$ transparent conductive electrodes (FTO, $\left.\mathrm{TEC}^{\mathrm{TM}} \mathrm{A} 8\right) 8$ 
Ohm/square were purchased from Pilkington NSG Group.

\section{B. Preparation of $\mathrm{ZnO}$ Photoanodes Sensitized with $N-719$}

$\mathrm{ZnO}$ nanocrystalline films were prepared by the sol-gel method. A small proportion of $\mathrm{Zn}\left(\mathrm{NO}_{3}\right)_{2}$ was added in n-propanol at $80^{\circ} \mathrm{C}$ followed by the addition of APPG with different molecular weights under stirring to modify surface morphology. Three different solutions were prepared by varying APPG molecular weight. Solution 1 was consisted of $0.357 \mathrm{~g} \mathrm{Zn}\left(\mathrm{NO}_{3}\right)_{2}$, 6ml n-propanol and $0.218 \mathrm{~g} \mathrm{APPG} 230$. Solution 2 was consisted of $0.357 \mathrm{~g} \mathrm{Zn}\left(\mathrm{NO}_{3}\right)_{2}, 6 \mathrm{ml}$ n-propanol and $0.252 \mathrm{~g}$ APPG400 and solution $30.950 \mathrm{~g}$ $\mathrm{Zn}\left(\mathrm{NO}_{3}\right)_{2}, 6 \mathrm{ml} \mathrm{n-propanol} \mathrm{and} \mathrm{0.8g} \mathrm{APPG2000} \mathrm{(Fig.} \mathrm{1).} \mathrm{FTO}$ glasses were dipped into each solution and a thin film was deposited before calcination at $500^{\circ} \mathrm{C}$ for $15 \mathrm{~min}$. This step was repeated several times in order to achieve optimal film thickness. After cooling down at room temperature, $\mathrm{ZnO}$ films attached strongly to the FTO were immersed in a $5 \times 10^{-4} \mathrm{M}$ (50:50 ethanol: acetonitrile) N719 solution for $24 \mathrm{~h}$. Dye coated $\mathrm{ZnO}$ photoelectrodes were rinsed with acetonitrile to remove non-attached dye molecules and dried at $50^{\circ} \mathrm{C}$ before use.

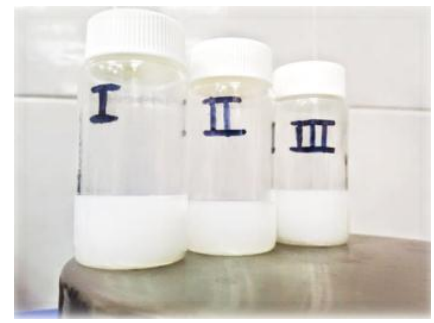

Fig. 1. Preparation of $\mathrm{ZnO}$ solutions.

\section{Preparation of Gel Electrolyte and Fabrication of Quasi Solid State Dye Sensitized Solar Cells}

A gel electrolyte with an organic-inorganic hybrid material was prepared according to a procedure described in previous publications [16], [17]. Briefly, poly(propylene glycol) bis (2-aminopropyl ether) $M_{r}=230$ and 3-isocyanatopropyl triethoxysilane (ICS) with molar ratio ICS/diamine=2, react in a vessel (acylation reaction), producing urea connecting groups between the polymer units and the inorganic part. The gel electrolyte was synthesized by the following procedure: $0.7 \mathrm{~g}$ of the functionalized alkoxide precursor (PPG230-ICS) were dissolved in $1.6 \mathrm{~g}$ of sulfolane and $0.8 \mathrm{~g}$ of methoxypropionitrile under stirring. Then, $0.6 \mathrm{ml}$ of glacial acetic acid $(\mathrm{AcOH})$ were added to accelerate gelation followed by $0.3 \mathrm{M}$ 1-methyl-3-propylimidazolium iodide, $0.1 \mathrm{M}$ LiI and $0.05 \mathrm{M} \mathrm{I}_{2}$ in a final molar ratio AcOH:LiI:MPII: $\mathrm{I}_{2}=2.5: 0.1: 0.3: 0.05$. To complete the electrolyte solution, $0.204 \mathrm{~g}$ of tert-butyl pyridine and $0.036 \mathrm{~g}$ of guanidine thiocyanate were added to the above mixture. The still liquid electrolyte was placed on the top of the $\mathrm{ZnO}$ electrodes and a platinized FTO counter electrode was pushed by hand on the top to complete the cell. The electrolyte was finally gelled after several hours. The platinized FTO glass was made by casting a few drops of a $\mathrm{H}_{2} \mathrm{PtCl}_{6}$ solution $(5 \mathrm{mg} / 1 \mathrm{ml}$ of ethanol) and calcination at $450^{\circ} \mathrm{C}$ for $15 \mathrm{~min}$. The active area of the as prepared cells was $2 \mathrm{~cm}^{2}$.

\section{Characterization of Quasi-Solid State Dye Sensitized Solar Cells}

The samples were illuminated with Xe light source using a Solar Light Co. solar simulator (model 16S-300) equipped with AM 0 and AM 1.5 direct Air Mass filters to simulate solar radiation at the surface of the earth. The light intensity was $100 \mathrm{~mW} / \mathrm{cm}^{2}$. J-V curves were recorded by connecting the cells to a Keithley Source Meter 2601A. A black mask $0.264 \mathrm{~cm}^{2}$ was used in the measurements. For each case, we made three devices which were tested under the same conditions in order to avoid any misleading estimation of efficiency. The structural properties of the films were evaluated with field emission scanning electron microscopy (FE-SEM). Electrochemical impedance spectroscopy (EIS) was also used for the interface characterization of individual components of the cells.

\section{RESULTS AND DISCUSSION}

The structural properties of the films were initially studied by images of the three nanostructured photoanodes using FE-SEM (Fig. 2). The smaller the size of nanoparticles, the more porous film is generated which results in higher specific surface area and therefore a greater amount of dye is adsorbed.
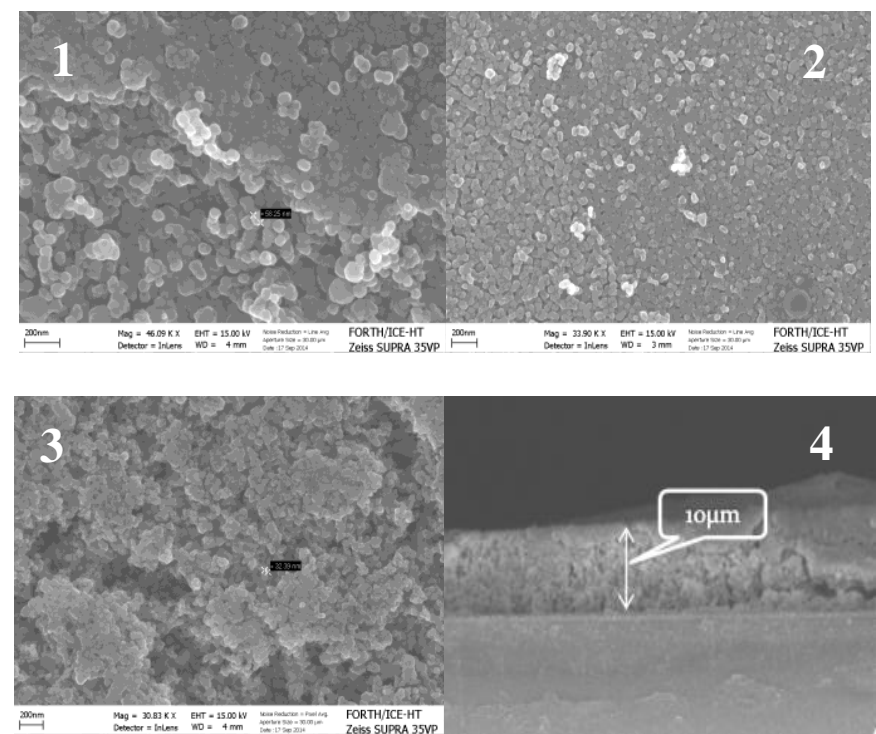

Fig. 2. SEM top view from $\mathrm{ZnO}$ photoanodes 1, 2, and 3 made of APPG230, APPG400, APPG200 as templates respectively. 4. Cross-section image for sample 3

In the first case the large size of nanoparticles $(58.3 \mathrm{~nm}$ diameter) results in poor dye adsorption, while in the third case, where nanoparticles exhibit the smallest size $(32.4 \mathrm{~nm})$, the amount of dye adsorption is greater. The cross-section image from the most efficient photoanode was found to be $10 \mu \mathrm{m}$.

The structural properties of the $\mathrm{ZnO}$ films were also characterized with porosimetry method. The total pore volume $\left(V_{p}\right)$, ranged from 0.045 to $0.106 \mathrm{~cm}^{3} / \mathrm{g}$ for the three samples. The BET specific surface area $(S)$, the total pore volume $\left(V_{p}\right)$, the mean pore diameter $D_{p o r}$ and the total porosity $(\varphi)$ were calculated for all samples and they are presented in Table I. 
TABLE I: BRUNAUER-EMMETT-TELLER (BET) MEASUREMENTS

\begin{tabular}{lllll} 
Cell & $V_{p}\left(\mathrm{~cm}^{3} / \mathrm{g}\right)$ & $S\left(\mathrm{~m}^{2} / \mathrm{g}\right)$ & $\varphi(\%)$ & $D_{p o r}(\mathrm{~nm})$ \\
\hline 1 & 0.045 & 13.04 & 20 & 12.7 \\
2 & 0.098 & 22.47 & 35 & 15.2 \\
3 & 0.106 & 26.44 & 37 & 14.2 \\
\hline \hline
\end{tabular}

Nitrogen adsorption-desorption isotherms are shown in Fig. 3.

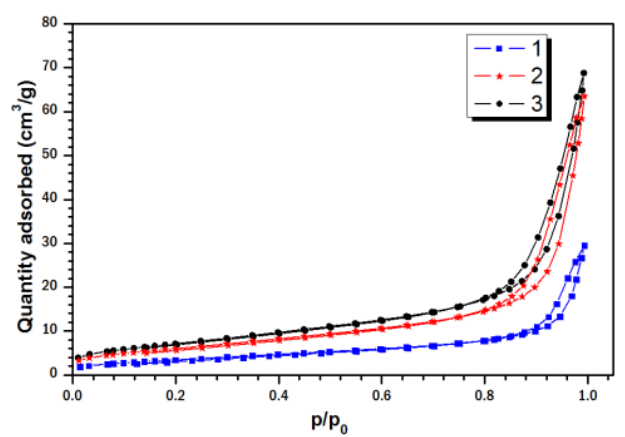

Fig. 3. Nitrogen adsorption-desorption isotherms of three $\mathrm{ZnO}$ samples used as photoanodes.

The sample 3 seems to exhibit higher pore volume compared to the other two photoanodes and thus growth of the specific area. The behavior of the pore volume affects the porosity, which defines the quantity of dye adsorption. X-ray diffraction patterns were used to identify the synthesized zinc oxide nanoparticles. The polycrystalline X-ray diffraction for the third sample is presented in Fig. 4. All the typical diffraction peaks are referred to wurtzite $\mathrm{ZnO}$ phase.

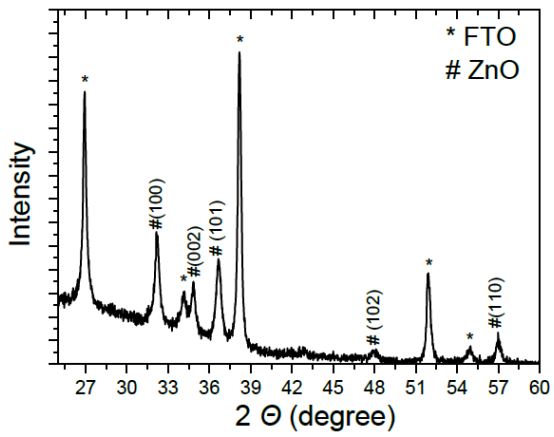

Fig. 4. X-ray diffraction pattern for zinc oxide film made of APPG2000 as organic template.

$\mathrm{ZnO}$ were successfully used as photoanodes in DSSCs. The current density-voltage $(\mathrm{J}-\mathrm{V})$ characteristic curves of quasi solid-state dye sensitized solar cells based on $\mathrm{ZnO}$ are presented below in Fig. 5 .

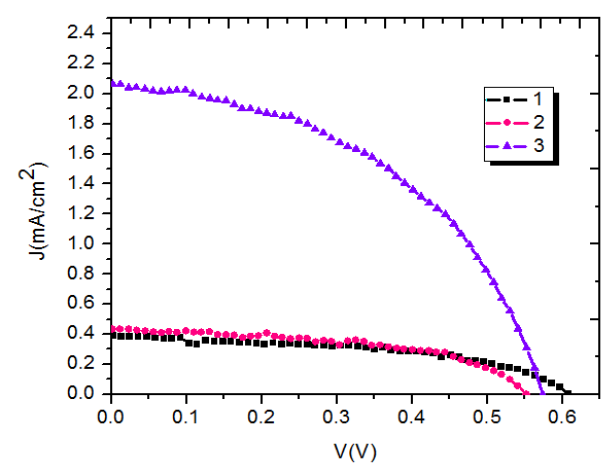

Fig. 5. J-V plots of DSSCs based on $\mathrm{ZnO}$ photoanodes.
The quasi solid-state DSSCs constructed with a combination of $\mathrm{Zn}\left(\mathrm{NO}_{3}\right)_{2}$ and APPG2000 exhibits improved performance, with an increase in current density compared with the other oligomers (Table II). This means that faster electron transport and by extension lower recombination rate occurs in the third case.

TABLE II: ELECTRICAL CHARACTERISTICS OF DSSCS EMPLOYING DIFFERENT ZINC OXIDE PHOTOANODES

\begin{tabular}{cccccc}
\hline \hline Cell & $J_{s c}\left(\mathrm{~mA} / \mathrm{cm}^{2}\right)$ & $V_{o c}(\mathrm{~V})$ & $P_{\max }(\mathrm{mW})$ & $F F$ & $n \%$ \\
\hline 1 & 0.392 & 0.607 & 0.036 & 0.50 & 0.12 \\
2 & 0.430 & 0.551 & 0.037 & 0.52 & 0.12 \\
3 & 2.080 & 0.574 & 0.166 & 0.47 & 0.56 \\
\hline \hline
\end{tabular}

The effect on the electron transport at the interfaces in the DSSCs under simulated solar light can be investigated with electrochemical impedance spectroscopy (EIS). Fig. 6(a) shows the Nyquist plot while Fig. 6(b) the Bode plot obtained from cells with $\mathrm{ZnO}$ photoanodes. The charge transfer resistance at the counter electrode $\left(R_{p t}\right)$ is represented as a semicircle in the impedance spectra and a peak in the Bode phase angle plot.

The resistance element related to the response in the intermediate frequency represents the charge transport at the $\mathrm{ZnO} /$ dye/electrolyte interface $\left(R_{t r}\right)$ and shows diode like behavior. The semicircle at the low frequency is attributed to the diffusion in the electrolyte $\left(R_{d i f}\right)$.

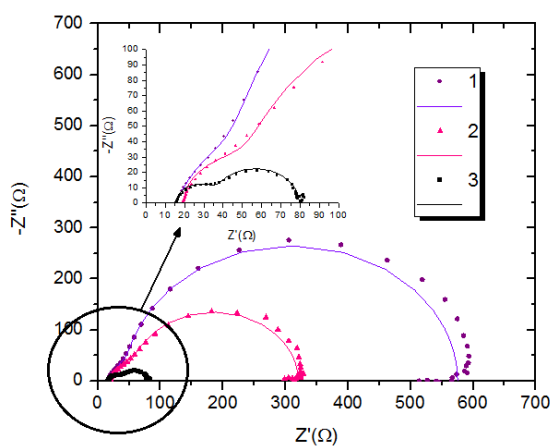

(a)

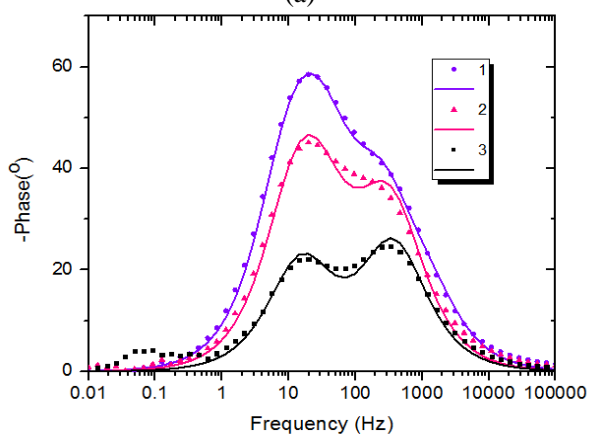

(b)

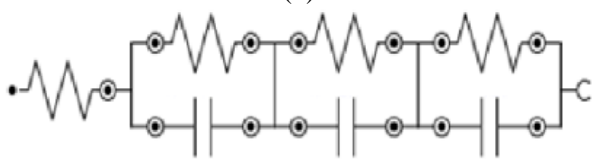

(c)

Fig. 6. (a) Nyquist, (b) Bode diagrams for the three $\mathrm{ZnO}$ films obtained from electrochemical impedance spectroscopy under 1 sun illumination and (c) Equivalent circuit from fitted parameters.

From the fitted parameters for the three cells the equivalent circuits were $\mathrm{R}(\mathrm{RC})(\mathrm{RC})(\mathrm{RC})$ for cell 1 (Fig. 6(c)) and $\mathrm{R}(\mathrm{RC})(\mathrm{RC})$ for the 2 and 3 cells. $J_{s c}$ values appeared at Table 
III are in general qualitatively consistent with the $R_{p t}$ and $R_{t r}$ values of these cells at Table II. Two factors that limit the short-circuit photocurrent are the efficiency of collecting the injected electrons at the transparent back contact and the catalytic ability of the counter electrode for the reduction of $I_{3}{ }^{-}$ions to $I^{-}$ions. If $R_{t r}$ is low the efficiency of collecting the injected electrons at the transparent back contact increases, which results in an increase to the rate of electron transfer in the circuit and thereby the short circuit photocurrent of the pertinent DSSC. Besides, if $R_{p t}$ is also low, the rate of reduction of $I_{3}{ }^{-}$ions and creation of $I^{-}$ions increases resulting an increase to the rate of regeneration of oxidized dye, the injection of electrons from the regenerated dye and thereby the $J_{s c}$. Finally, $R_{\text {dif }}$ concerning the diffusion rate of $I_{3}{ }^{-}$and $I$ ions in the gel electrolyte is also consistent to $J_{s c}$. Smaller measured values for $R_{d i f}$ has beneficial effect to the $J_{s c}$ and overall efficiency values.

The mid-frequency peak at Bode plots could be used to estimate the electron lifetime $(\tau)$ for the prepared solar cells. This can be calculated from the angular frequency $\left(f_{\min }\right)$ at the mid frequency peak using $\tau=1 /\left(2 \pi f_{\text {min }}\right)$. The values for electron lifetime are also presented in Table IV. From electron lifetime measurements we can extract the conclusion that in the case of the APPG2000 an increase to the electron lifetime is measured which means a more effective suppression of the back reaction of the injected electrons with $\mathrm{I}_{3}^{-}$in the electrolyte. The low and high frequency peaks observed in the Bode plots correspond to triiodide diffusion in the electrolyte and charge transfer at the counter electrode, respectively.

TABLE III: ELECTROCHEMICAL IMPEDANCE SPECTROSCOPY FITTED PARAMETERS FOR DSSCS EMPLOYING DIFFERENT ZINC OXIDE PHOTOANODES

\begin{tabular}{cccccccc}
\hline \hline Cell & $\begin{array}{c}R_{h} \\
(\Omega)\end{array}$ & $\begin{array}{c}R_{p t} \\
(\Omega)\end{array}$ & $\begin{array}{c}C_{p t}\left(10^{-4}\right) \\
(\mathrm{F})\end{array}$ & $\begin{array}{c}R_{t r} \\
(\Omega)\end{array}$ & $\begin{array}{c}C_{t r}\left(10^{-3}\right) \\
(\mathrm{F})\end{array}$ & $\begin{array}{c}R_{d i f} \\
(\Omega)\end{array}$ & $\begin{array}{c}C_{d i f}\left(10^{-1}\right) \\
(\mathrm{F})\end{array}$ \\
\hline 1 & 16 & 26.6 & 0.382 & 528 & 0.0540 & 4.25 & 0.00033 \\
2 & 19.9 & 34.2 & 0.252 & 267 & 0.0776 & - & - \\
3 & 15.5 & 20.8 & 0.320 & 43.2 & 0.3540 & - & - \\
\hline \hline
\end{tabular}

TABLE IV: ELECTRON LIFETIME OF CORRESPONDING CELLS

\begin{tabular}{ccc}
\hline \hline Cell & $f(\mathrm{~Hz})$ & $\tau(\mathrm{msec})$ \\
\hline 1 & 20.29 & 7.85 \\
2 & 20.29 & 7.85 \\
3 & 16.02 & 9.94 \\
\hline \hline
\end{tabular}

\section{CONCLUSION}

Three different $\mathrm{ZnO}$ photoanodes were prepared and tested under 1 sun illumination. The incorporation of the highest molecular weight oligomer APPG2000, improves dye adsorption, and this found to be the most critical parameter related to the conversion efficiency. Dye sensitized solar cells employing gel electrolyte and $\mathrm{ZnO}$ photoanode showed an overall efficiency of $0.6 \%$ which was found that it was strongly affected by the nanostructure of $\mathrm{ZnO}$ films. Future research will be focused on the fabrication of advanced $\mathrm{ZnO}$ nanostructures with improved porosity and smaller particle size, which will offer an enhancement in the DSSCs' efficiency.
NOMENCLATURE

\begin{tabular}{|c|c|c|}
\hline Name & Symbol & Units \\
\hline $\begin{array}{l}\text { Sheet resistance of } \\
\text { the FTO substrate }\end{array}$ & $R_{h}$ & $\Omega$ \\
\hline $\begin{array}{l}\text { Charge resistance at } \\
\text { the counter electrode }\end{array}$ & $R_{p t}$ & $\Omega$ \\
\hline $\begin{array}{l}\text { Charge transport } \\
\text { resistance at the } \\
\mathrm{ZnO/dye/electrolyte}\end{array}$ & $R_{t r}$ & $\Omega$ \\
\hline $\begin{array}{l}\text { Diffusion resistance } \\
\text { in the electrolyte }\end{array}$ & $R_{d i f}$ & $\Omega$ \\
\hline $\begin{array}{l}\text { Capacity of the } \\
\text { electrolyte/counter } \\
\text { electrode interface }\end{array}$ & $C_{p t}$ & $\mathrm{~F}$ \\
\hline $\begin{array}{l}\text { Capacity of the } \\
\text { negative electrode/ } \\
\text { electrolyte interface }\end{array}$ & $C_{t r}$ & $\mathrm{~F}$ \\
\hline $\begin{array}{l}\text { Capacity of the } \\
\text { carrier diffusion in } \\
\text { the electrolyte }\end{array}$ & $C_{d i f}$ & $\mathrm{~F}$ \\
\hline Total pore volume & $V_{p}$ & $\mathrm{~cm}^{3} / \mathrm{g}$ \\
\hline Specific surface area & $S$ & $\mathrm{~m}^{2} / \mathrm{g}$ \\
\hline Total porosity & $\varphi$ & $\%$ \\
\hline Mean pore diameter & $D_{\text {por }}$ & $\mathrm{nm}$ \\
\hline $\begin{array}{l}\text { Short circuit current } \\
\text { density }\end{array}$ & $J_{s c}$ & $\mathrm{~mA} / \mathrm{cm}^{2}$ \\
\hline Open circuit voltage & $V_{o c}$ & V \\
\hline Maximum power & $P_{\max }$ & $\mathrm{mW}$ \\
\hline Fill factor & $F F$ & - \\
\hline Overall Efficiency & $n$ & $\%$ \\
\hline Frequency & $f$ & $\mathrm{~Hz}$ \\
\hline Electron lifetime & $\tau$ & msec \\
\hline
\end{tabular}

\section{ACKNOWLEDGMENT}

The authors would like to acknowledge that their research has been co-financed by the European Union (European Social Fund - ESF) and Greek national funds through the Operational Program "Education and Lifelong Learning" of the National Strategic Reference Framework (NSRF) Research Funding Program: Thales MIS: 377756.

\section{REFERENCES}

[1] A. Hagfeldt, G. Boschloo, L. Sun, L. Kloo, and H. Pettersson, "Dye-sensitized solar cells," Chemical Reviews, vol. 110, pp. 6595-6663, November 2010.

[2] M. Grätzel, "Dye-sensitized solar cells," Journal of Photochemistry and Photobiology C: Photochemistry Reviews, vol. 4, pp. 145-153, October 2003.

[3] M. Zi, M. Zhu, L. Chen, H. Wei, X. Yang, and B. Cao, "ZnO photoanodes with different morphologies grown by electrochemical deposition and their dye-sensitized solar cell properties," Ceram. Int., vol. 40, pp. 7965-7970, January 2014.

[4] S. Zhu, X. Tian, J. Chen, L. Shan, X. Xu, and Z. Zhou, “A facile approach to construct multiple structured $\mathrm{ZnO}$ crystals by Trisodium citrate-assisted hydrothermal growth toward performance enhancement of dye-sensitized solar cell," J. Phys. Chem. C., vol. 118, pp. 16401-16407, December 2014.

[5] K. Lee, E. S. Lee, B. Yoo, and D. H. Shin, "Synthesis of ZnO-decorated $\mathrm{TiO}_{2}$ nanotubes for dye-sensitized solar cells," Elect. Acta., vol. 109, pp. 181-186, July 2013.

[6] R. A. Rani, A. S. Zoolfakar, J. Subbiah, J. Z. Ou, and K. Kalantar-Zadeh, "Highly ordered anodized $\mathrm{Nb}_{2} \mathrm{O}_{5}$ nanochannels for dye-sensitized solar cells," Ele. Com., vol. 40, pp. 20-23, March 2013.

[7] R. A. Rani, A. S. Zoolfakar, J. Subbiah, J. Z. Ou, R. A. Kadir, H. Nili, K. Latham, et al., "Reduced impurity-driven defect states in anodized nanoporous $\mathrm{Nb}_{2} \mathrm{O}_{5}$ : The possibility of improving performance of photoanodes," Chem. Commun., vol. 49, pp. 6349-6351, May 2013.

[8] B. Y. Jeong and E. H. Jung, "Micro-mountain and nano-forest pancake structure of $\mathrm{Nb}_{2} \mathrm{O}_{5}$ with surface nanowires for dye-sensitized solar cells," Met. Mater. Int., vol. 19, pp. 617-622, May 2013. 
[9] Q. Zhang, C. S. Dandeneau, X. Zhou, and G. Cao, "ZnO nanostructures for dye-sensitized solar cells," Adv. Mater., vol. 21, pp. 4087-4108, July 2009.

[10] I. Gonzalez-Valls and M. Lira-Cantu, "Vertically-aligned nanostructures of $\mathrm{ZnO}$ for excitonic solar cells: A review," Energy Environ. Sci., vol. 2, pp. 19-34, November 2009.

[11] F. $\mathrm{Xu}$ and L. Sun, "Solution-derived $\mathrm{ZnO}$ nanostructures for photoanodes of dye-sensitized solar cells," Energy Environ. Sci., vol. 4, pp. 818-841, December 2010.

[12] C. Zeng, S. Xie, M. Yu, Y. Yang, and X. Lu, "Facile synthesis of large-area $\mathrm{CeO}_{2} / \mathrm{ZnO}$ nanotube arrays for enhanced photocatalytic hydrogen evolution," J. Pow. Sour., vol. 247, pp. 545-550, February 2013.

[13] H. A. Wahab, A. A. Salama, A. A. El-Saeid, O. Nur, M. Willander, and I. K. Battisha, "Optical, structural and morphological studies of $(\mathrm{ZnO})$ nano-rod thin films for biosensor applications using sol gel technique," R. in Phys., vol. 3, pp. 46-51, February 2013.

[14] K. J. Chen, F. Y. Hung, S. J. Chang, and Z. S. Hu, "The crystallized mechanism and optical properties of sol-gel synthesized $\mathrm{ZnO}$ nanowires," J. of Ele., Soc., vol. 157, pp. 241-245, January 2010.

[15] N. H. Alvi, M. U. Ali, S. Hussain, O. Nur, and M. Willander, "Fabrication and comparative optical characterization of $\mathrm{n}-\mathrm{ZnO}$ nanostructures (nanowalls, nanorods, nanoflowers and nanotubes)/p-GaN white-light-emitting diodes, " Scr. Mater., vol. 64 pp. 697-700, April 2011.

[16] Y. Chen, E. Stathatos, and D. D. Dionysiou, "Sol-gel Modified $\mathrm{TiO}_{2}$ powder films for high performance dye-sensitized solar cells," J. of Photochemistry and Photobiology A: Chem., vol. 203, pp. 192-198, April 2009.

[17] E. Stathatos, "Organic-inorganic nanocomposite materials prepared by the sol-gel route as new ionic conductors in solid state electrolytes," Ionics, vol. 11, pp. 140-145, November 2005.

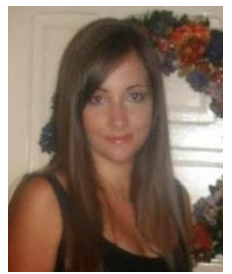

Andigoni Apostolopoulou received her diploma in physics from University of Patras, Greece in 2010 and her M.Sc. degree in energy and environment from the same university in 2013. She is a $\mathrm{PhD}$ candidate at the Department of Physics, University of Patras since 2013. Andigoni Apostolopoulou has published her research in peer reviewed scientific journals and international conferences. Her field of research focuses on third generation photovoltaics, materials science and building integration of photovoltaics.

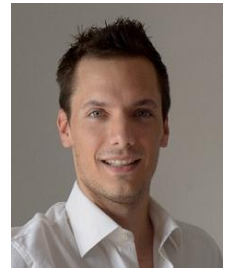

Dimitrios Karageorgopoulos got his diploma in physics followed by a master's degree in electronics and computer science at the University of Patras, Greece in 2010. As an undergraduate student, he worked on the development of a computer based automatic method to measure the surface conductivity of semi-conductive samples, according to the Van Der Pauw technique of four-point probes. Currently he is a $\mathrm{PhD}$ student at the Department of Physics, University of Patras. His specific research interest is focused on the third generation solar cells (based on dyes, perovskites, quantum dots).

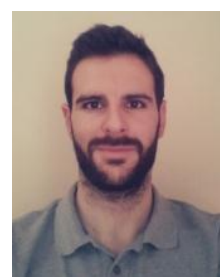

Andreas Rapsomanikis is an electrical engineer with the Technological Institute of Western Greece since 2013, he currently works at Nanotechnology and Advanced Materials Laboratory at Technological Institute of Western Greece. He is a M.Sc. candidate at the Department of Geology, University of Patras, studying environmental sciences. Andreas Rapsomanikis has published his research in peer reviewed scientific journals. His field of research includes dye-sensitized solar cells, photocatalytic applications, electrochromic devices, and perovskite solar cells.

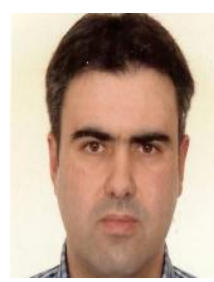

Elias Stathatos was born in 1968 in Patras, Greece. He obtained his first degree in physics from University of Patras and then his Ph.D. degree from the Engineering Science Department, University of Patras. Prof. Stathatos was a postdoctoral research fellow in University of Cincinnati, USA at the Civil \& Environmental Engineering Dept. Professor Stathatos is the head of the Nanotechnology and Advanced Materials Laboratory and he has more than 100 publications in peer review journals and five chapters in books which are recognized of more than 3500 citations ( $h$-factor $=30$ ). He is an editorial board member of Journal of Advanced Oxidation Technologies, Materials Science in Semiconductor Processing (Elsevier), International Journal of Photoenergy and Heliyon (Elsevier). 